\title{
Wild Rubber Extraction in the Peruvian Amazon: local perception and socioeconomic indicators as tools for decision-making
}

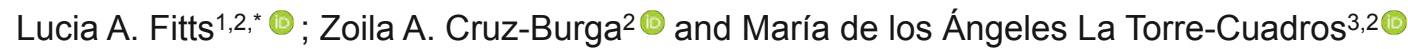

\begin{abstract}
Forests play an important role in the life of indigenous communities. However, making nontimber forest management a profitable economic activity is a difficult task. Factors contributing to this difficulty include the increasing pressure from the market economy, which leads communities to opt for alternative economic activities such as agroforestry, timber harvest, cacao, and aquaculture. External institutions have implemented rubber projects to reintroduce the rubber extraction activity, but the outcomes of these projects are unknown. To help address this issue, our research was conducted in the Sinchi Roca I native community in Peru. The objectives were (1) to describe the process of wild rubber (Hevea brasiliensis) extraction; (2) to analyze the local perception by gender of rubber management; and (3) to evaluate the outcomes of this activity using socioeconomic criteria and indicators. Data collection techniques included in-depth interviews, focus group discussions, and intra-household surveys. First, we found that locals once extracted rubber with unsuitable techniques, which have improved with technical forest management. Second, wild extraction has a positive socioeconomic perception for the community, mainly because it provides income for basic needs. Surveyed families extract around 28,800 liters of rubber per year, averaging US $\$ 557.80$ per family each year. Finally, we found that men and women participate in wild rubber extraction and decisionmaking. However, women prefer not to actively participate in meetings with external institutions. Despite the benefits found, current use of silviculture techniques and community empowerment should be improved to take better advantage of existing potential.
\end{abstract}

Keywords: Gender participation; Kakataibo; Traditional Knowledge; Non-Timber Forest Products; Multivariate Analysis

1Department of Forest Resources, University of Minnesota, Saint Paul, United States

2 Grupo de investigación Sistemas Socioecológicos y Servicios Ecosistémicos. Facultad de Ciencias Forestales. Universidad Nacional Agraria La Molina. Av. La Universidad s/n. La Molina, Lima 12, Perú

3 Facultad de Ciencias Ambientales, Universidad Científica del Sur, Carr. Panamericana Sur Km 19, Villa el Salvador, Lima 42, Perú.

* Corresponding author. $\triangle E$ E-mail address: LAF (fitts010@umn.edu), ZACB (zcruz@lamolina.edu.pe), MALTC

(mlatorrec@ucientifica.edu.pe) 


\section{SIGNIFICANCE STATEMENT}

For decades, rubber has been an important resource in Amazonian communities offering a sustainable economic activity that complements the main sources of income such as agriculture. However, how projects by external institutions performed is still unknown. By knowing the actual outcomes of the rubber projects conducted in native communities, we can prioritize forest management practices that go along with community interests and provide a sustainable alternative. These alternatives together with other management actions, can contribute to the conservation of a highly biodiverse ecosystem. We demonstrate how governance, job opportunities, and income have increased after implementing technical forest management. We also show the role of women in rubber management compared to their minor role in other communities and the potential for growth of rubber extraction.

\section{INTRODUCTION}

Forests and their many resources have played an important economic, social and cultural role in the lives of indigenous communities who have a high dependency on forest biodiversity for their livelihoods (Coomes et al. 2016; Godoy et al. 2002; Khasa and Dancik 1996; Schaafsma et al. 2014). Worldwide, there are around 479.6 million indigenous people which represent $6.2 \%$ of the world's population (ILO 2019). Indigenous population influence the management of at least $28 \%$ of the land surface (FAO and UNEP 2020; Garnett et al. 2018) and look after $80 \%$ of the world's biodiversity (World Bank 2016).

Given this great biodiversity that exists in forestlands and the amount of indigenous communities that depend on natural resources, forest management has become a key alternative to the traditional harvesting of forest products to reach a sustainable use of natural resources. Moreover, during the last century, native communities have become stakeholders in forest management projects, which created the term of community forest management (CFM). CFM basically refers to the type of forest management where communities actively participate in a technical forest management (De-Camino 2000; FAO 2010; Sabogal et al. 2008). CFM efforts have been seen all over the world with various approaches and techniques (some with support of external agents), resulting in diverse and at times contradictory outcomes (Bowler et al. 2012; FAO 2010; Mansuri and Rao 2004; Pagdee et al. 2006).

The success of community forest management projects might be due to the implementation of certain strategies. These strategies include: co-management; a clear definition of the rights, duties and responsibilities; the strengthening of local capacities and community organizations; the participatory design; the integral or ecosystemic approach; the implementation of flexible and responsive policies to local needs; ensuring access and ownership of resources; as well as rigorous and continuous monitoring of the results of the project's design (Álvarez et al. 2004; Álvarez and Shany 2012; Bowler 2012; IIAP 2004; Kajembe et al. 2006; Nguyen et al. 2008).

Examples of CFM efforts in Asia have shown an improvement in governance, social capital (organization and planning) and empowerment after CFM for timber and non-timber products. Economic benefits for 
locals, new jobs and better distribution of resources were also seen after CFM. However, some of the efforts were lost after projects with external institutions were completed (Dev et al. 2003; Mahanty et al. 2009; Rebugio et al. 2010). Another example from CFM is shown in Africa, where CFM improved forest health and increased locals' quality of life (Kajembe et al. 2006).

One of the areas that has received a lot of attention in CFM efforts using various strategies is Latin America. However, these efforts have had disparate levels of success like in Asia: some efforts were lost, and projects were abandoned. CFM in Latin America is usually carried out jointly with external agents, which generally are nongovernmental organizations (NGOs) (FAO 2010). Furthermore, CFM is focused primarily on timber products (FAO 2010). Despite the many efforts with CFM done in Latin America, just around $3.5 \%$ of production forests in the region are under management (ITTO 2005a). There are however some efforts in Mexico and Guatemala that demonstrate that CFM is successful for conservation strategies in a similar way as natural protected areas, and builds a better local economy (Bray et al. 2008; FAO 2010).

Out of the many Latin American countries where CFM has been practiced, Peru represents a high potential, but has not had the results expected despite the large amounts of resources invested for short periods which is evidenced by the scarce adoption and diffusion of CFM pilot experiences (Medina et al. 2008). In Peru, forestry is not a priority activity and accounts for no more than one percent of the country's Gross Domestic Product (Held et al. 2015). This is due to the use of forests by indigenous communities just for subsistence purposes or for commercializing a few products with little added value. Other reasons for the disappointing levels of success of CFM efforts are that communities sign agreements with third parties selling standing trees to companies, generally under disadvantageous conditions for local communities (AIDESEP 2013; Sabogal et al. 2008; Vera 2014). However, there have been a few CFM efforts with timber products under a Forest Stewardship Council (FSC) certification, which were successful. These efforts brought economic benefits, improvement in social capital, and better infrastructure (Bueno et al. 2006; Nalvarte 2015). There have also been some successful CFM efforts with non-timber products in Loreto and Madre de Dios (Peru) with Mauritia flexuosa, Euterpe oleracea, and with ecotourism (Gaviria and Sabogal 2013).

These prior CFM efforts around the world have demonstrated that in developing countries is not a homogeneous solution (Álvarez et al. 2004; Álvarez and Shany 2012; Bowler et al. 2012; FAO 2010; IIAP 2004; Kajembe et al. 2006; Sabogal et al. 2008). In contrast, community forestry adopts different approaches, some of which work better than others (Shyamsundar and Ghate 2011). The comparison of the results of these studies is difficult, however, because of the use of single-case analysis, the lack of common indicators, different methodology or context, and poor study design (Bowler et al. 2012; Pagdee et al. 2006; Rasolofoson et al. 2015). Therefore, it should not be expected that different CFM would be equally effective in relation to their criteria and indicators, even if those projects had the same design (Padgee et al. 2006).

Throughout the different applications of CFM around the world, different criteria and indicators have been used to measure success and there is no consensus on how 
that success should be measured. This lack of consensus might be due to the diversity in communities' structure and context which make every study use different criteria and indicators, sometimes adapting preexistent protocols to local contexts (i.e. FAO n.d.; ITTO 2005b). Some examples of indicators used in CFM research include family and community income, economic and financial indexes, jobs and business management, security and sustainability of the resources, benefits of forest products, conservation of the forest, vitality of forest ecosystems and natural resource management, and perception of the families on the forest management, among other indicators (Dev et al. 2003; Nalvarte 2015; Ríos-Cortez et al. 2012).

In Peruvian Amazon communities, the use of rubber was a traditional activity and was used for lining fabrics and shoes to make them waterproof as well as to make other tools and utensils (GIZ 2012; WWF-UK 2014). However, it is during the 19th and the beginning of the 20th century, when the Rubber Boom intensified its use (due to its high potential for application in industry) and marked an important epoch for rubber extraction in the Amazon (Jaramillo-Giraldo et al. 2017). However, the way rubber was extracted in that time negatively impacted indigenous people in the Amazon. Impacts included mobilizing and mixing ethnic groups between regions or countries, who were later enslaved, tortured and murdered for not meeting the quotas for extraction demanded by the great rubber houses' foremen that obeyed international demand (Barclay 2012; Chirif 2011; García 2001; Uribe 2013).

Even though these negative experiences occurred, indigenous communities continue to use rubber on their own initiative or due to external agents as NGOs, International Aid Cooperatives and National Forest
Conservation Programs. Examples of these institutions working with rubber in the Amazon are the German Society for International Cooperation GIZ (working in the Pichis river - GIZ 2012), the Research Institute of the Peruvian Amazon (IIAP) together with the Fondo para el Desarrollo de Servicios Estratégicos INCAGRO (working in the Madre de Dios region) (Velarde et al. 2010), the WWF-Peru together with USAID (also working in Madre de Dios) who provide technical support and assistance to rubber production and export to the company Empresa Comunal Jebe Natural del MAP Tahuamanu ECOMUSA (WWF 2015a). All these activities related to rubber extraction are aimed at conserving the forest and improving local livelihoods. Rubber projects usually are worked together with other economic activities such as timber, cocoa, and coffee. Therefore, rubber is often a complementary economic alternative to other livelihoods and prioritized by some local communities.

Despite communities' interest in working with rubber, little research focuses on rubber extraction in all Peruvian Amazon, centering the attention on the Madre de Dios region. Furthermore, only some of the studies are published as institutional reports and handbooks but not in scientific journals. The published literature is focused on the social and historical level in relation to the rubber boom but not on the management of the resource itself, except in Brazil, where we find most of the current literature on rubber extraction. Among the current literature, some studies center their attention on the importance of the Brazilian rubber tappers in the $80 \mathrm{~s}$ grassroots movements, which established extractive reserves to conserve forest (Gomes et al. 2012; Gonçalves de Oliveira and Vidotte 2016). Similarly, other authors express a concern about how rubber 
tappers are changing their activity to livestock mainly due to the low profitability of rubber extraction (Salisbury and Schmink 2007). Furthermore, some authors focus on analyzing the properties of natural rubber (Peres and Pastore 2019; Posadas et al. 2016; Trovatti et al. 2016).

There is an increasing concern from NGOs, local communities, National and Subnational governments which involves what is happening in Peru and specifically to how rubber management is conducted in natural forests, its importance to the conservation of natural forests, its contribution to communities' livelihoods as a potential sustainable economic activity (IIAP 2009; Peres and Pastore 2019; WWF-UK 2014) and the outcomes of rubber projects implemented over the years. This concern requires an urgent need to address to prioritize conservation efforts and forest management in Peru. To tap into this issue, this research was designed as a case study in the Sinchi Roca I native community in Peru. The main objectives were (1) to describe the process of wild rubber extraction, (2) to analyze the local perception with respect to the forest management of rubber, and (3) to evaluate the outcomes of this activity using socioeconomic criteria and indicators. The importance and originality of this study is that it explores if there were actual changes after various short-term forestry projects that involved rubber and if it is worth it to invest resources to enhance rubber extraction, which has been part of their economic activities for decades. Our results can be used as a tool for decisionmaking to prioritize conservation efforts and forest management activities. This study uses a set of criteria and indicators that are clear, measurable and were elected considering local conditions.

\section{MATERIAL AND METHODS}

\section{Study area}

The study was carried out in February 2016 at the native community Sinchi Roca I, located in the departments of Ucayali and Huanuco, Peru. The community is located $25 \mathrm{~km}$ upstream of the San Alejandro River, six hours from Pucallpa, in the central Amazonian forest of Peru (Figure 1). This area belongs to the Tropical Wet Forest (Twf) and Tropical Premontane Wet Forest (TP-wf) (Holdridge 1987). The predominant climate is warm and humid (tropical). According to the Köppen-Geiger classification, the average annual temperature in the area is $26.1{ }^{\circ} \mathrm{C}$, while the average annual rainfall is $3329 \mathrm{~mm}$. The area does not flood, with moderate drainage and with a surface layer of decomposing organic waste of approximately $20 \mathrm{~cm}$. Clay loam soils and sandy clay loam, with the $\mathrm{pH}$ varying between 4.96 and 6.65 , are found (Quinteros 2001).

Sinchi Roca I belongs to the ethnic group Kakataibo (Pano linguistic family) and has 827 inhabitants in 110 families (MINSA-Perú 2015). The community has 23986 hectares (ha) entitled to them, out of which 18752 ha correspond to the forest management area, according to the Management Plan of 2011. However, for rubber management, the community also uses territory outside of their legal boundaries, which were their territories in the past. The community's main economic activities are slash-and-burn agriculture, fishing, hunting, extraction of forest products and handicrafts.

Until 2015, the community had a contract with a company, Forestal Nieto S.A.C., to harvest timber in the forest management area. The company used the Management Plan of 2011, which originally included a 
supplementary management plan for rubber (Hevea brasiliensis (Willd. ex A. Juss.) Müll. Arg). Due to a breach of the plan, the Peruvian Forest's Supervision Institution (OSINFOR) cancelled the community's permission to extract timber. Currently, the community continues extracting rubber from the area originally occupied by the company.

\section{Data collection}

\section{Description of rubber extraction}

We collected local information via indepth interviews (as described in Bernard 2006) from five community members regarding the historic and current activity of rubber extraction, which helped us have a general background and understanding of how the activity has developed and how it affects the economy and social life of people. The interviews had a semi-open questionnaire. The questionnaire included the following topics: current use of forests and how it has changed over time, what projects and institutions have worked in the area, sources of external support for forest management activities and the community's perception with respect to forestry activities, among other topics according to observed interests. From these in-depth interviews, we synthesized an account of how extracting rubber developed over the years. Authorities interviewed were the community leader, the lieutenant governor, the president of the forestry oversight committee, the president of FENACOCA (The Native Federation of the Kakataibo Communities) who was also a community leader before, and a female leader (president of the Glass of Milk association). In addition, two focus group discussions (Bernard 2006) were held, one with the rubber association (with 25 participants, all male) and the other one with

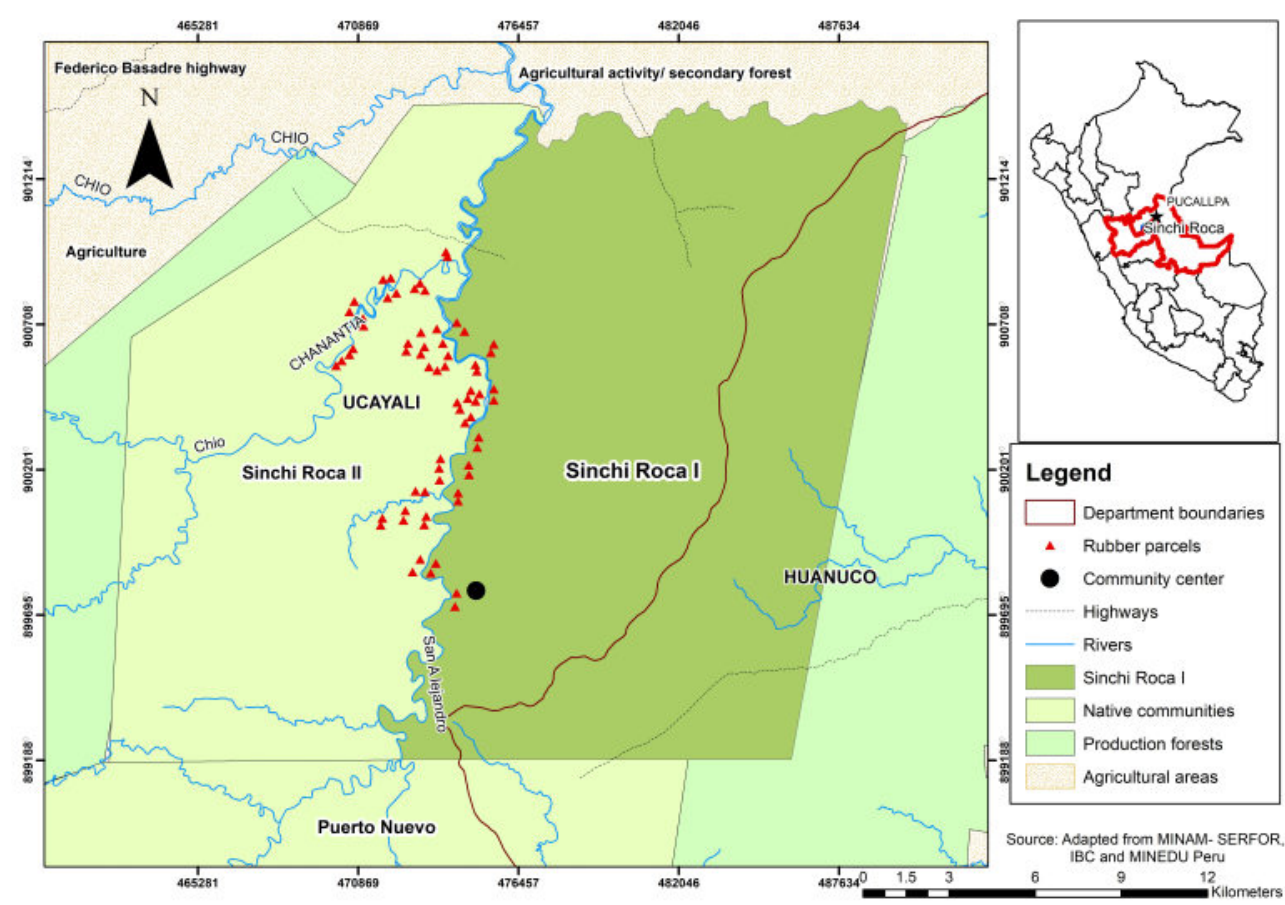

Figure 1. Location of Sinchi Roca I. Triangles represent the rubber parcels (local name: estrada) managed by the rubber committee. Locations of the parcels are along the San Alejandro River for easier access and transportation of the product. These locations were identified by locals through participatory maps. 
women who are involved in forest activities (15 participants). We considered important to do a separate focus group with women exclusively because of the community's social structure, in which women do not feel free to express their opinion if men are around. In both focus groups, we aimed to gather information on the use of forest resources (both timber and non-timber), the people's different perceptions on subjects regarding forestry activities, and projects and institutions that have previously worked with the community. At the end of the focus group discussion, locals worked on a participatory map to identify the use of resources, rubber extraction areas and areas of conflict.

\section{Perception of wild rubber extraction in Sinchi Roca I}

To measure the impact on and perception by families of rubber extraction, intrahousehold surveys (Bernard 2006) were conducted to the male and female heads of each household. This technique allowed us to compare gender opinions. The sample size was calculated based on 110 families (total present in the community) using the finite population formula (with values: $p=0.5$; $Z$ score=1.96, $d=0.125, \quad N=110$, formula described in Aguilar-Barojas 2015). We applied the 80 surveys to 41 families (39 women and 41 men). To obtain results from families who performed any forest management activity and families who did not, we used a stratified random sample technique to select our target families. We divided the sample into two categories $(50 \%$ of the samples in each category). Some family members that were surveyed had also participated in an in-depth interview but with different groups of questions. The surveys were composed of five sections: (1) Demographics, (2) Forestry activities performed in the community, (3) Perception of benefit and satisfaction on forest management activities, (4) Governance and participation in forestry activities, (5) Perception of forest status. Some of the topics on the surveys are not described here as they are out of the scope of this paper. The questionnaire included multiple choice, open ended questions, free-listing and tables to complete.

\section{Outcomes of wild rubber extraction}

\section{using socioeconomic criteria and} indicators

To identify the local perceptions of impacts of rubber management on socioeconomic aspects, we established 8 criteria and 17 indicators which are listed in the summary table at the end of the results section (Table 3 ). In this study, we propose a set of simplified criteria and indicators that could be replicated for similar research objectives. These criteria and indicators were selected and built-up combining proposed criteria and indicators from CIFOR (1999), FAO (n.d.), and ITTO (2005b), as well as some of our own. They were prioritized to accomplish the research objectives according to this community's context in the social and economic fields. We used these criteria and indicators to build our questions for the diverse data collection techniques described in this study. After collecting the information, we returned to these criteria and indicators to make a decision on each of them based on each outcome after the rubber management projects in the community

Furthermore, to verify the species of rubber (which is known by the common botanical name shiringa) used by the community, we collected three fertile botanical samples (with fruit), which were identified by the "Herbario MOL" at the Universidad Nacional Agraria La Molina. 


\section{Ethics}

We obtained the corresponding permission and consent from the community for data collection.

\section{Data analysis}

From the three techniques we used for data collection (focus groups, intrahousehold surveys, and in-depth interviews), we looked for systematic patterns in the qualitative data for perceptions and impacts of rubber extraction. Then, we combined qualitative and quantitative data which were tabulated in a database. We first explored the data with descriptive statistics to later conduct bi-variate and multivariate analysis.

We compared demographic variables collected during the surveys (gender, educational level, and age) with local perception on benefits and satisfaction towards rubber extraction (for both, the categories were yes and no) and the perception of forest status change in a tenyear period (categories: no change, improved, or worsen). Age was reclassified into three categories: [15-30>, [30-45>, [45+ years. Level of studies was also reclassified in two categories: primary school, and high school- higher education. The comparison between variables was conducted with Chisquare tests of independence. We used the chisq.test function in $\mathrm{R}$, with the Yates correction and a $95 \%$ confidence level. As a next step the compiled database was analyzed through a Multiple Correspondence Analysis (MCA) to further visualize the relationships between the demographic variables and our variables of interest (local perception of rubber extraction) in two dimensions. The MCA output plots the original variables against the new dimensions according to their mutual correlations (Chi et al. 2013). We used SPSS for Windows, Version 25 for the MCA. Finally, participatory maps that locals elaborated during the focus groups were digitized and processed with the ArcMap software. Once they were digitized, we overlaid the different participatory maps to obtain the areas where rubber is extracted.

\section{RESULTS}

The age of the surveyed people ranged between 16 and 80 years ( $\bar{X}=37)$. In each household, there was an average of six people (ranging from two to 11). As for their education level, $45 \%$ did not complete primary school, $28 \%$ had completed primary school, $18 \%$ began but did not complete high school, $6 \%$ finished high school and finally, the remaining $3 \%$ studied higher education (technical training, college or university degrees).

\section{Wild rubber extraction}

Sinchi Roca I members reported that around 60 families in the community (55\% of the families) extracted rubber by the 1950's, right after the Rubber Boom period. The extracting techniques, however, were inappropriate for the forest's health, as surrounding trees were unnecessarily cut down to ensure more space for extracting rubber. This lack of appropriate silvicultural techniques and the damage to the surrounding trees altered the natural regeneration of the rubber trees. Furthermore, due to this damaging technique, whereby they scrapped the rubber tree to extract the latex, the cambium was sometimes harmed, which caused the death of the tree. The equipment they used back then included a scraper tool and rubber bags (that were attached to the tree for 
collecting the product). Rubber bags were impractical for this purpose, so they were later replaced by plastic containers. The product underwent no quality control and was sold as a raw product, with no further transformation. Locals sold the product to intermediaries who later on sold it to industries for the manufacturing of natural latex-based products.

During the last 15 years, the community has signed several agreements with different external agents to extract rubber from their territories in exchange for some benefit. These benefits included training, equipment, infrastructure and jobs. However, these agreements were unclear, causing some troublesome situations in which these external agents would be dishonest on the amount of rubber that they extracted due to the little control locals had over their plots. These situations made many people stop extracting rubber. It was only between the years 2009 and 2012 that locals started selling the product again, but in a more manufactured form (field coagulated sheets, as described by WWFUK (2014) with the help of external institutions. Since 2012, the National Forestry Chamber of Peru (CNF for its Spanish acronym) and other institutions have carried out training sessions and workshops within the community, which has improved the quality of the activity, both for forest health and for the product itself. One rubber project carried out by the CNF in the community aimed to strengthen the technical skills of the committee members and to help them initialize the commerce.

The project also provided a facility equipped with machines for the manufacturing process. This project enhanced the creation of a rubber committee. This committee is a mixedgender association whose objective is the sustainable use and management of rubber through improving the processing techniques and by coordinating its commerce as a unique entity. The rubber committee has 35 members ( 31 men and 4 women); each of them has one or two parcels (containing 150-180 rubber trees each) where they extract wild rubber. They usually work with their spouses in their parcel. Each member works independently, but the committee later collects the product and sells it together; the income is then distributed proportionally.

Nowadays, both men and women work early in the morning extracting rubber. Usually the process takes around four to five hours, and then they go to their agricultural parcels or perform other daily chores. Rubber parcel locations can be observed in Figure 1. Rubber is extracted only during the dry season (March-October) as in the rainy period, the latex is diluted in the tree. In general, protective measures for extracting forest resources related to clothing and basic equipment are not implemented by locals. The heat, the discomfort, and the lack of tradition are the main reasons for the workers not to use protective equipment. For rubber extraction, only boots are used as a safety measure. However, in the past fewer people wore boots and instead, most wore sandals for walking in the forest.

The members of the committee reported that they store rubber either in a liquid state or processed as sheets. The product is then commercialized in the cities of San Alejandro, Pucallpa or Lima. Figure 2 shows the rubber extraction process in the community.

We found that Sinchi Roca I inhabitants perform some forest care, but there were no defined techniques with a clear purpose. The population does not carry out technical management activities. For rubber parcels, 


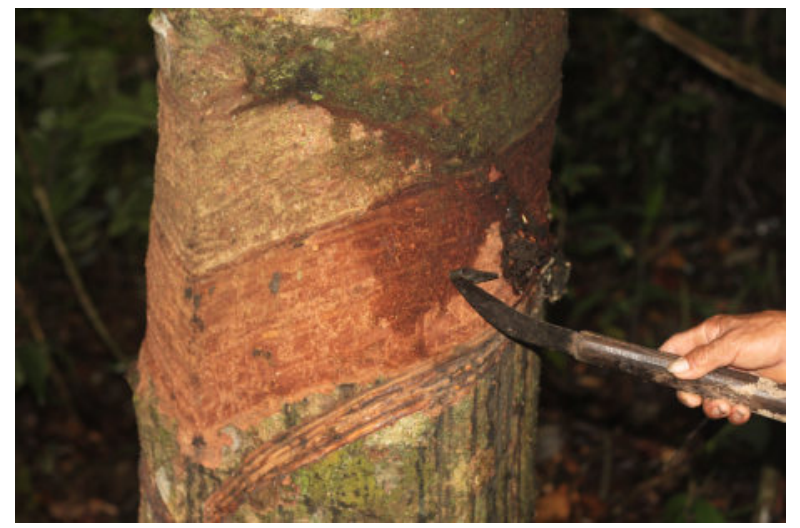

A

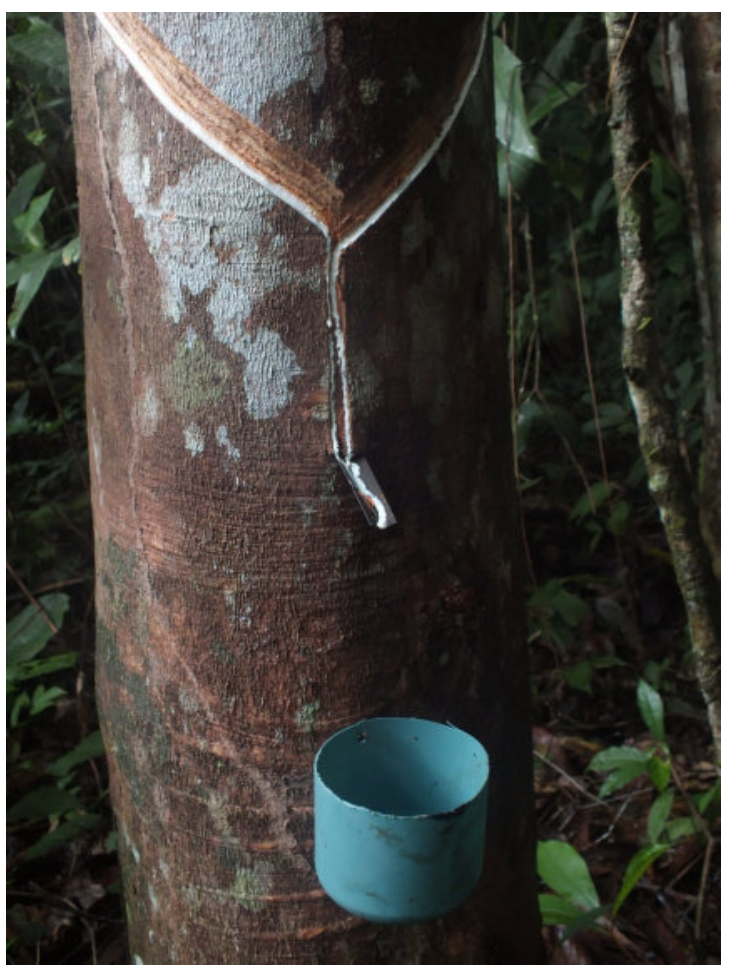

B

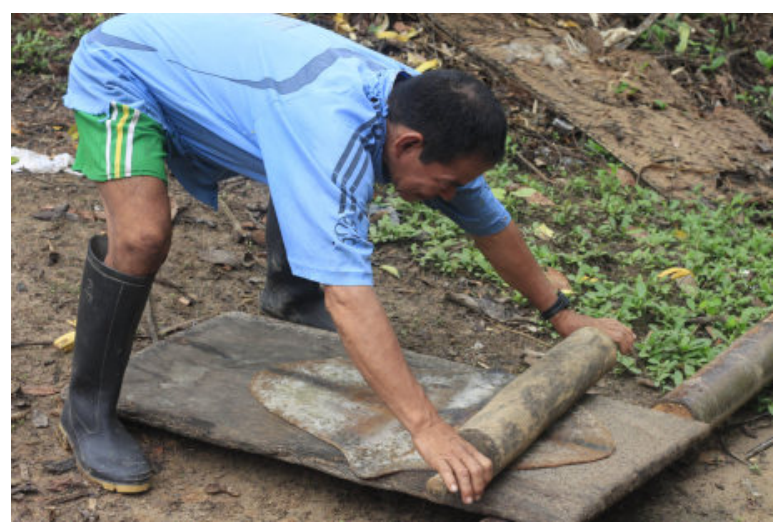

C

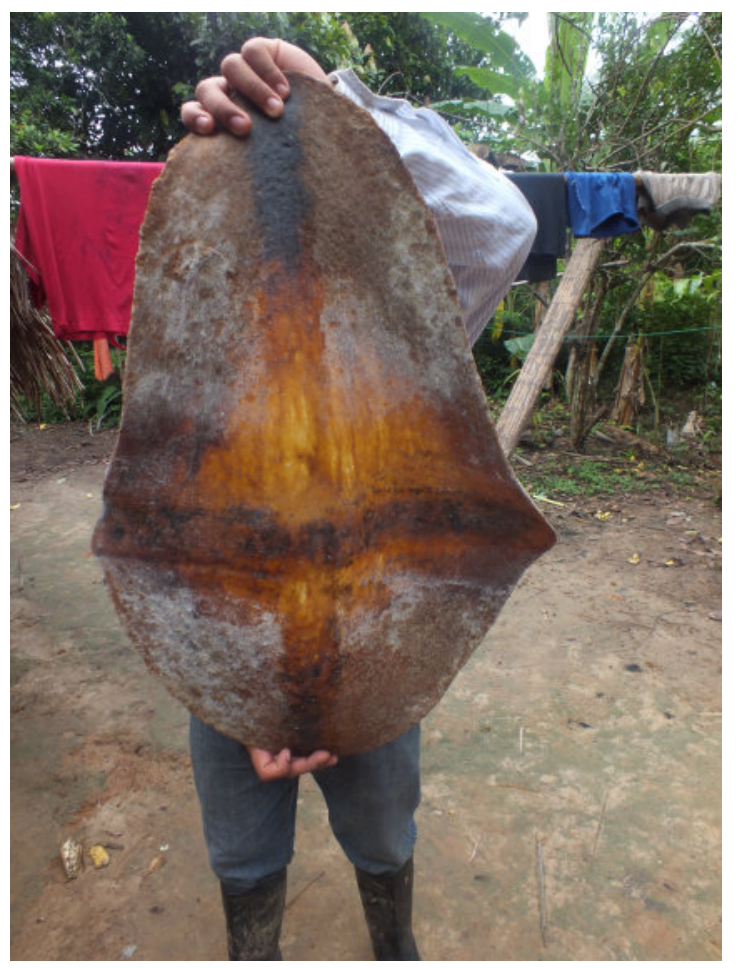

D

Figure 2. Wild rubber extraction and processing by locals. Panels $A$ and $B$ show the extraction process. $C$ and $D$ show the rubber sheets after processing.

each member of the committee is responsible for providing the necessary maintenance to their parcels, which include cleaning and weeding of the trails and cutting branches or fallen trees (or those about to fall) blocking the road. Because their extraction activities are generally done at a very small-scale, the population commented that they do not have the need to carry out any additional technical activities related to forest care, nor do they have enough training to carry out such activities. On the other hand, due to regular training sessions and workshops (done by the CNF and The National Commission for Development and Life without DrugsDEVIDA), the locals have now improved their harvesting techniques: they are very careful with how the cut in the tree is made to avoid introducing diseases to the tree or damaging the cambium. In addition, they regulate the amount of formic acid and other 
components they use in the processing of the product to avoid affecting its quality.

\section{Perception of wild rubber management}

To understand local perceptions of rubber management, we studied its perceived benefits and satisfaction. Among the benefits, the most representative is that extracting rubber provides income for basic needs followed by job opportunities (See Figure 3). Respondents commented that there are rubber trees dispersed throughout their territory, which represent big potential if a greater effort is devoted to harvesting this product (See Figure 1 for current location of rubber parcels).

Of the surveyed population $(n=80), 72 \%$ indicate being satisfied with rubber extraction activity (Figure 3). Among the major reasons for satisfaction are the following: the activity creates income (39\%), gives job opportunities (15\%), and is sustainable $(13 \%)$. It is thus inferred that the main reason for satisfaction with the activity is the economic benefit it brings. On the contrary, informants report that the main reasons for dissatisfaction with the rubber extraction activity were the following: the person surveyed is not employed in the field, so he does not receive any benefits $(10 \%)$, it was more profitable in the past $(5 \%)$, and there is not enough support from external institutions (4\%) (Figure 3). Among these reasons, locals emphasized the lack of support from external institutions. A second point of dissatisfaction mentioned was that in the past, the activity was more profitable. In recent years, natural rubber has dropped in price $(-1 \$$ per $\mathrm{kg})$ and thus, the intensity of its extraction has decreased.

Results from the Chi-square tests of independence and the MCA show relationships between predictor and demographic variables (Table 1 and Figure 4). The only significant relationship between the variables for both tests was gender and perception of forest condition.

The MCA analysis allowed us to further visualize the relationships between the demographic variables and our variables of interest in different dimensions. The results from the MCA are presented in a twodimensional scatter plot (Figure 4). The first and second dimensions (horizontal and vertical axis) explain $51 \%$ of the total variability (dimension one $=28 \%$; dimension two $=23 \%$ ). The vertical axis is an indicator of gender differences. A high score of this dimension is related to gender perception: women perceived dissatisfaction while men

Table 1. Chi-square tests of independence between demographic variables and perception of benefits, satisfaction and forest condition $(n=80)$. Significant results are marked by ${ }^{*}$. Where: $\mathrm{df}=$ degrees of freedom and $p$ is the $p$-value

\begin{tabular}{ccccccccccc}
\hline Variables & \multicolumn{3}{c}{ Age } & \multicolumn{4}{c}{ Gender } & \multicolumn{3}{c}{ Level of studies } \\
\cline { 2 - 10 } & $\boldsymbol{X}^{2}$ & $\mathbf{d f}$ & $\mathbf{p}$ & $\boldsymbol{X}^{2}$ & $\mathbf{d f}$ & $\mathbf{p}$ & $\boldsymbol{X}^{2}$ & $\mathbf{d f}$ & $\mathbf{p}$ \\
\hline $\begin{array}{c}\text { Perception of } \\
\text { benefits }\end{array}$ & 0.5711 & 2 & 0.75 & 0.2489 & 1 & 0.62 & 0.0124 & 1 & 0.91 \\
$\begin{array}{c}\text { Perception of } \\
\text { satisfaction }\end{array}$ & 3.057 & 2 & 0.21 & 3.2905 & 1 & 0.07 & 0.6317 & 1 & 0.43 \\
$\begin{array}{c}\text { Perception of } \\
\text { forest condition }\end{array}$ & 3.5951 & 4 & 0.46 & 7.5001 & 2 & $\mathbf{0 . 0 2 3 5 ^ { \star }}$ & 2.6066 & 2 & 0.27 \\
\hline
\end{tabular}




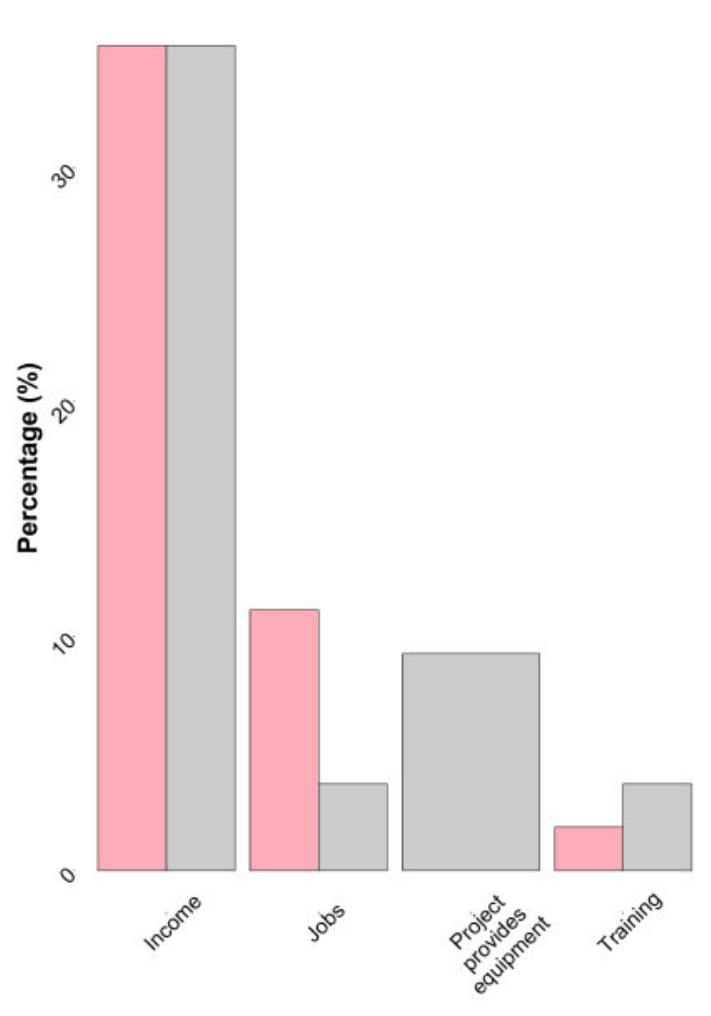

Perceived benefits

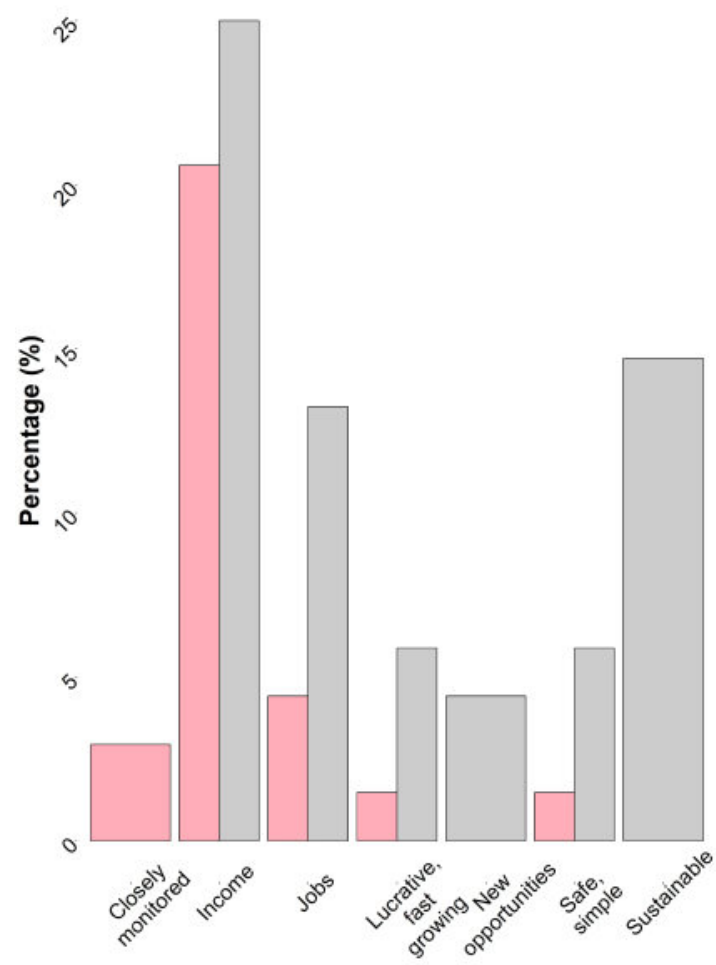

Perceived satisfaction

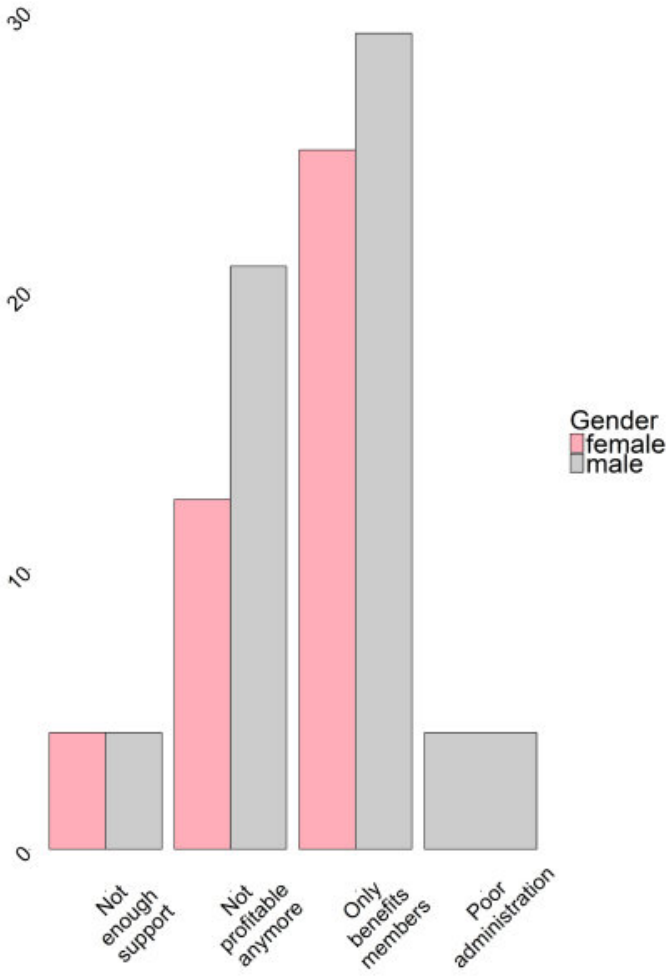

No benefits perceived

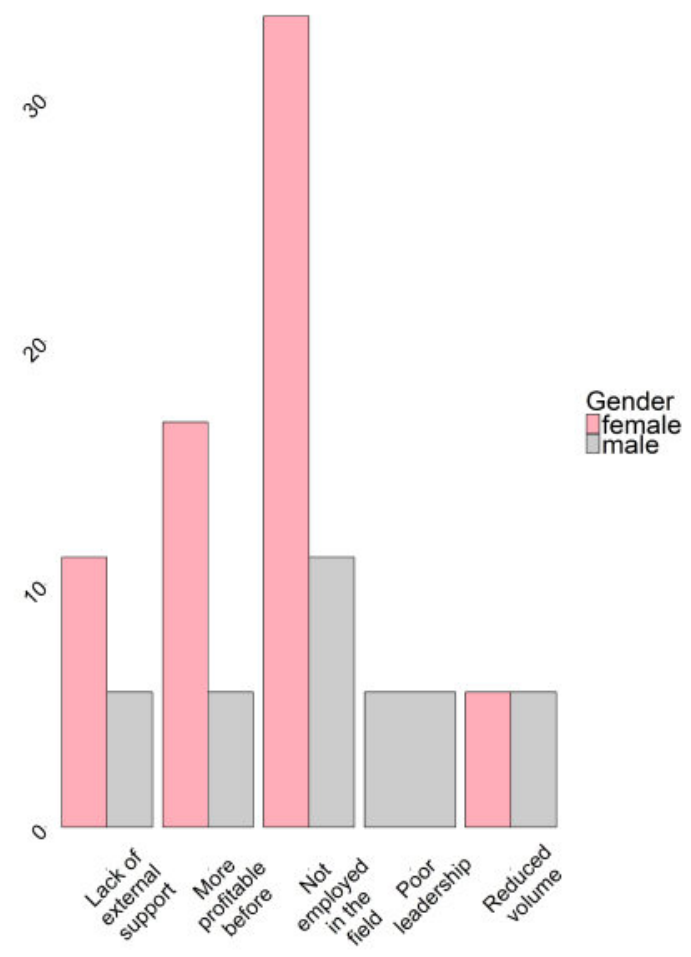

No satisfaction perceived

Figure 3. Local perception on rubber extraction activity $(n=80)$. Respondents were allowed to mention more than one reason for their perception of benefits and satisfaction; therefore, percentages might add up to more than $100 \%$. Answers were open ended and assigned to common categories during data analysis. 
were satisfied with rubber extraction. The horizontal axis is related to the perception of forest condition. We observed that women perceive that the forest remains the same (before and after implementing technical forest management), while men do perceive a change (either that it improved or worsened); this result is also shown in the independence tests. It should be noted that only 10 out of the 80 respondents mentioned that the forest's condition had improved (Figure 4). In addition, we observe that perception of rubber benefits is the least explanatory variable in dimension one and gender in dimension two. Also, the MCA has difficulties in assigning the education level variable to any dimension given its similar score in both while the contribution of age to perception was correlated to the perception of forest condition (Table 2).

\section{Socioeconomic outcomes of wild management}

\section{Social outcomes}

Sinchi Roca I native community holds several meetings in their communal room, where members discuss topics of interest. We reviewed seven community record books where there were 47 general community meetings concerning forest management issues. Out of the topics discussed, the main ones were management documents $(27 \%$ of the meetings), invasions of their territory by external agents (16\%), a contract with the Forestal Nieto S.A.C. logging company $(13 \%)$, contracts or agreements with other institutions (11\%), requests for money and support from the logging company $(9 \%)$, the rubber projects $(7 \%)$, illegal logging $(5 \%)$,

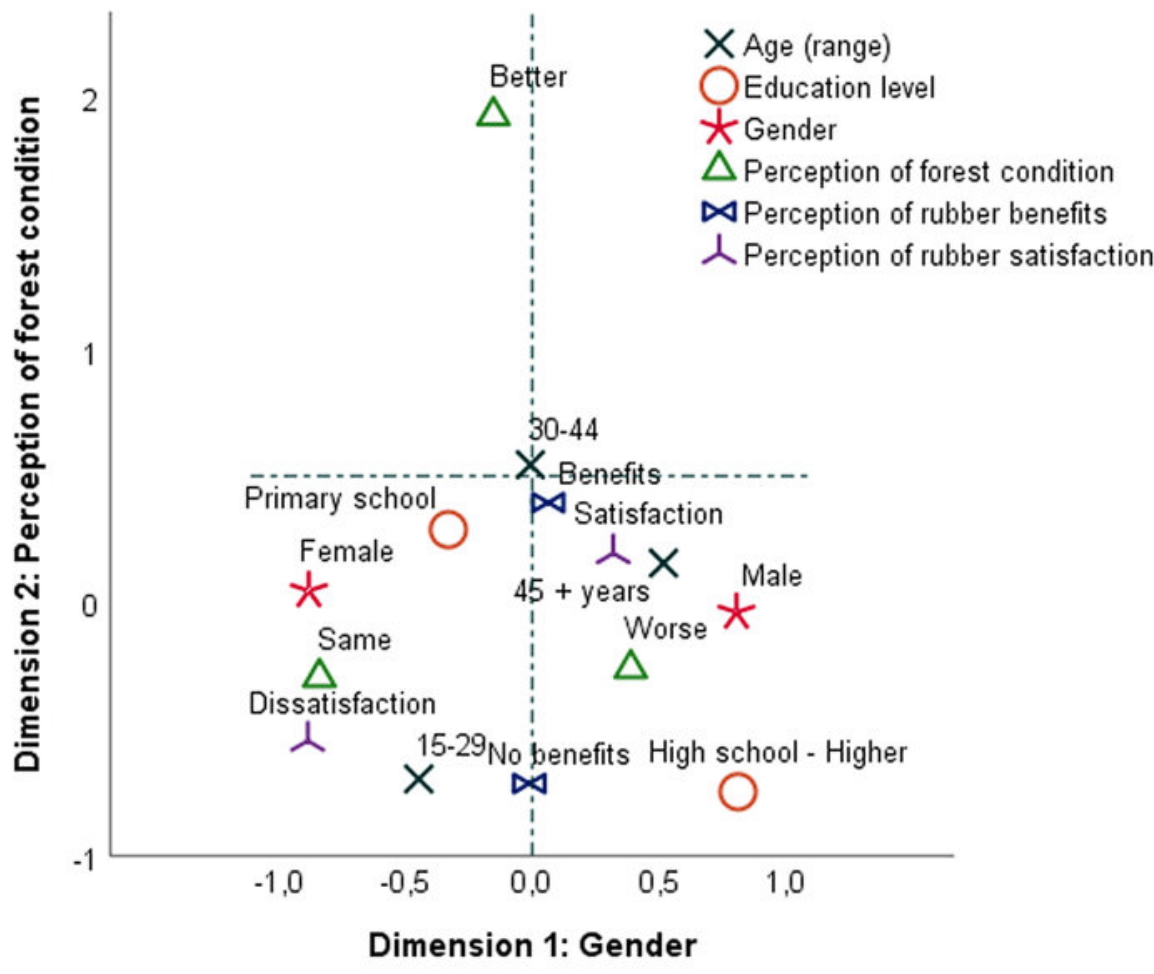

Figure 4. Representation of the two-dimensional solution of the MCA. Data derived from female and male intra-household surveys $(n=80)$ about perception of rubber extraction (benefits and satisfaction) 
Table 2. Discrimination measures for each variable and dimensions in multiple correspondence analysis (The higher the value of the discrimination measure of a given variable in a given dimension, the higher the importance of that variable within that dimension. Highlighted in bold text are the most important variables for each dimension).

\begin{tabular}{lccc}
\hline \multicolumn{3}{c}{ Discrimination measures } \\
\cline { 2 - 3 } \multicolumn{1}{c}{ Variables } & \multicolumn{2}{c}{ Dimension } & \multirow{2}{*}{ Average } \\
\cline { 2 - 3 } Gender & $\mathbf{0 . 7 1 2}$ & 0.002 & 0.357 \\
Age (range) & 0.144 & 0.288 & 0.216 \\
Education level & 0.261 & 0.214 & 0.237 \\
Perception of rubber satisfaction & 0.25 & 0.094 & 0.172 \\
Perception of rubber benefits & 0.002 & 0.278 & 0.14 \\
Perception of forest condition & 0.288 & $\mathbf{0 . 5 2 7}$ & 0.407 \\
Total & 1.657 & 1.403 & 1.530 \\
\hline
\end{tabular}

the REDD + project $(4 \%)$, monitoring and control of resources $(4 \%)$, sales of medicinal plants $(2 \%)$, and finally, land use change issues $(2 \%)$. In addition to these meetings, NGOs and other institutions host training sessions in the Sinchi Roca l's communal room where locals interested in natural resource management participate.

Both men and women participate in training sessions done by external institutions and in the general community meetings related to natural resources. Of the people surveyed, $52 \%$ indicated that they always attend the training sessions (24\% men and $28 \%$ women), $30 \%$ attend on a frequent basis ( $20 \%$ men and $10 \%$ women), $15 \%$ attend on some occasions (6\% men and $9 \%$ women), and $3 \%$ (all women) mentioned that they never attend such meetings. Women indicated that they sometimes do not have time to attend such meetings due to house chores and the care of their children. In addition, both men and women indicated that they often live for several days at their farms, which are far from the communal meeting room, so they do not attend the training sessions. Furthermore, we observed that males express their opinions and make decisions more $(61 \%)$ than females $(39 \%)$.

\section{Economic outcomes}

Extracting rubber generates more jobs in the community than logging. According to the respondents, the activity generates between 30 to 40 direct jobs. It should be noted that these are the jobs recognized by the respondents, since the official members of the rubber committee who actively participate in the activity are 35 people and each of them usually works with their spouse. Thus, the number of jobs generated by this activity is, in fact, higher. However, in the last years, the activity has lost importance and some members of the committee have stopped extracting rubber to dedicate their time to cacao.

Sinchi Roca I inhabitants extract on average 110 to $160 \mathrm{ml}$ of latex per day from an adult rubber tree $(50-60 \mathrm{~cm}$ diameter at breast height $[\mathrm{dbh}])$. This latex still has 
impurities, so it goes through a casting process, in which about $5 \%$ of the volume is lost. If the final product is rubber sheets, $0.863 \mathrm{~kg}$ of rubber sheets are obtained per liter of latex. At the end of 2015 , the selling price for liquid rubber was US\$ 2.15 (1 US $\$=3.25$ PEN) per kilogram and US $\$ 1.04$ per liter. In 2015, the 19 families surveyed that participated in rubber activities extracted and commercialized in total 20796 liters of rubber and $1126.60 \mathrm{~kg}$ of solid latex (in the form of sheets); this altogether represents a total income of US\$ 24 022.37. In addition, the total annual costs that this activity generates are US\$ 13 424.31, which includes the equipment, supplies, food and workforce. Therefore, the annual net income for rubber was US\$ 10 598.06, which represents US $\$ 557.80$ per family per year.

The results of this study make clear that some improvements have been made but there is still unfulfilled potential. Therefore, at the end of our survey, we asked the respondents to give us recommendations for enhancing rubber extraction. This will help decision-making and future project designs in the community. They mentioned a list of 11 recommendations. The three main ones were giving more support to the rubber committee by providing them with materials and supplies and more job opportunities (23\%); perform a more continuous and organized work with greater dedication $(23 \%)$; and increase training $(21 \%)$. Other recommendations included enriching the proactivity of the association's board members, enriching the forest with rubber tree plantations, improving the quality of the product, and performing more silvicultural treatments.

\section{DISCUSSION}

Through our study and the literature reviewed, we observed that in Peru there is a high rubber extraction potential for both natural forests and agroforestry systems. However, due to the lack of adequate processing techniques and its subsequent placement on the market, the activity is generally not profitable if it does not have external support during the development of its value chain (IIAP 2009). Currently, the resource can be accessed through nontimber forest concessions on public domain lands and through permits on private lands (i.e. private farms and forests in indigenous communities) (SERFOR 2015). However, rubber concessions and permits requested from the Government are a minority in relation to the total amount of available forestry concessions and permits (only a $2 \%)$; and also, although there is a high demand for rubber products at the national level, national production barely represents $0.7 \%$ of imports (SERFOR 2020). These numbers demonstrate this great potential and the need for concrete actions to promote this activity.

An example of a company that managed to make the rubber activity profitable is ECOMUSA, a company in Madre de Dios (where $100 \%$ of the country's shiringa concessions are located). ECOMUSA works with four concessions and private properties benefiting 22 families. The success of this company is in part due to its partnership with external institutions such as WWF, ACCA, CARE and the Government (through the Fondebosque institution). Similarly, in the Amazon region, the Forest Program has been working with 136 families from seven native communities through the Asociación de Productores de Shiringa de Condorcanqui. This association sells and 


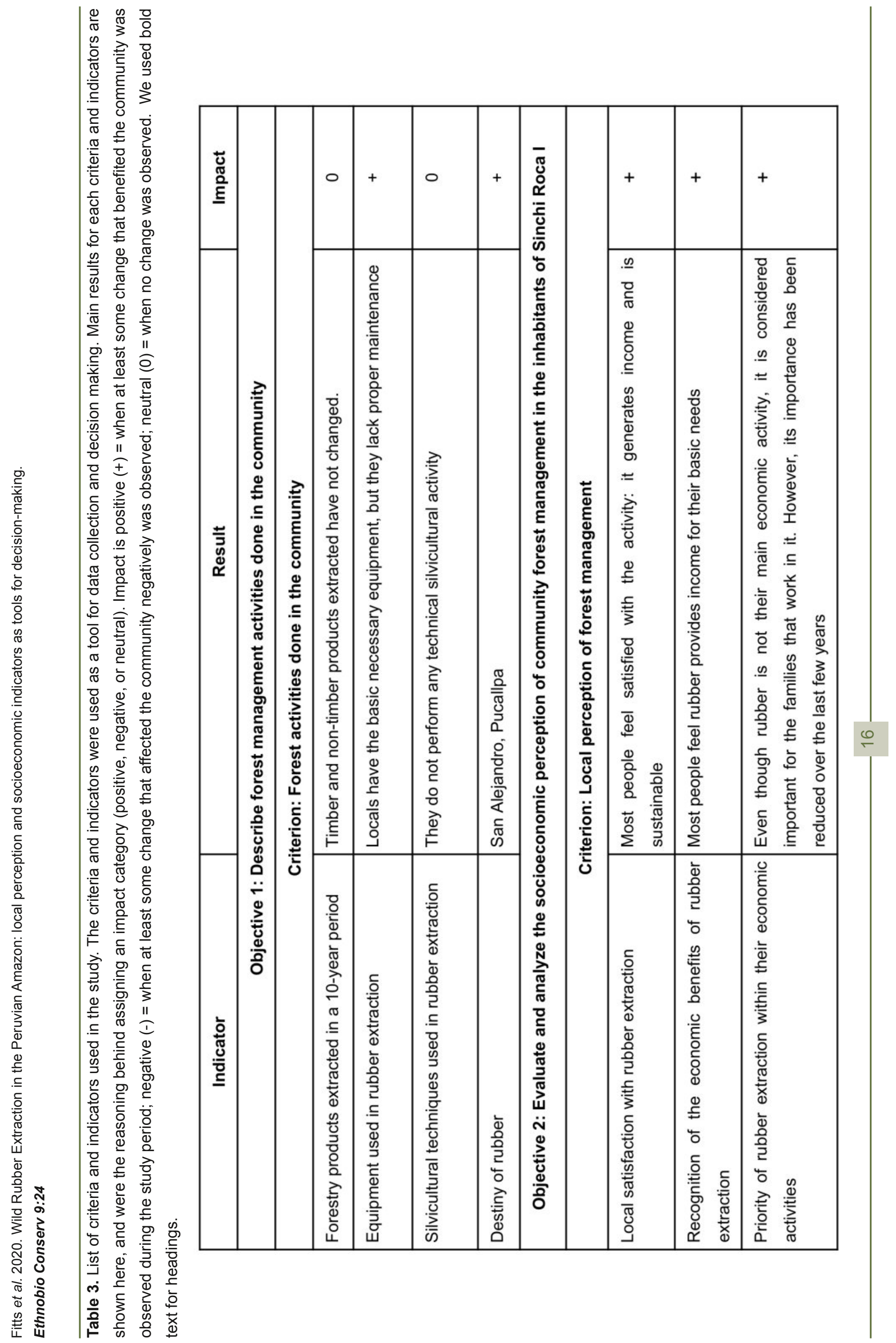




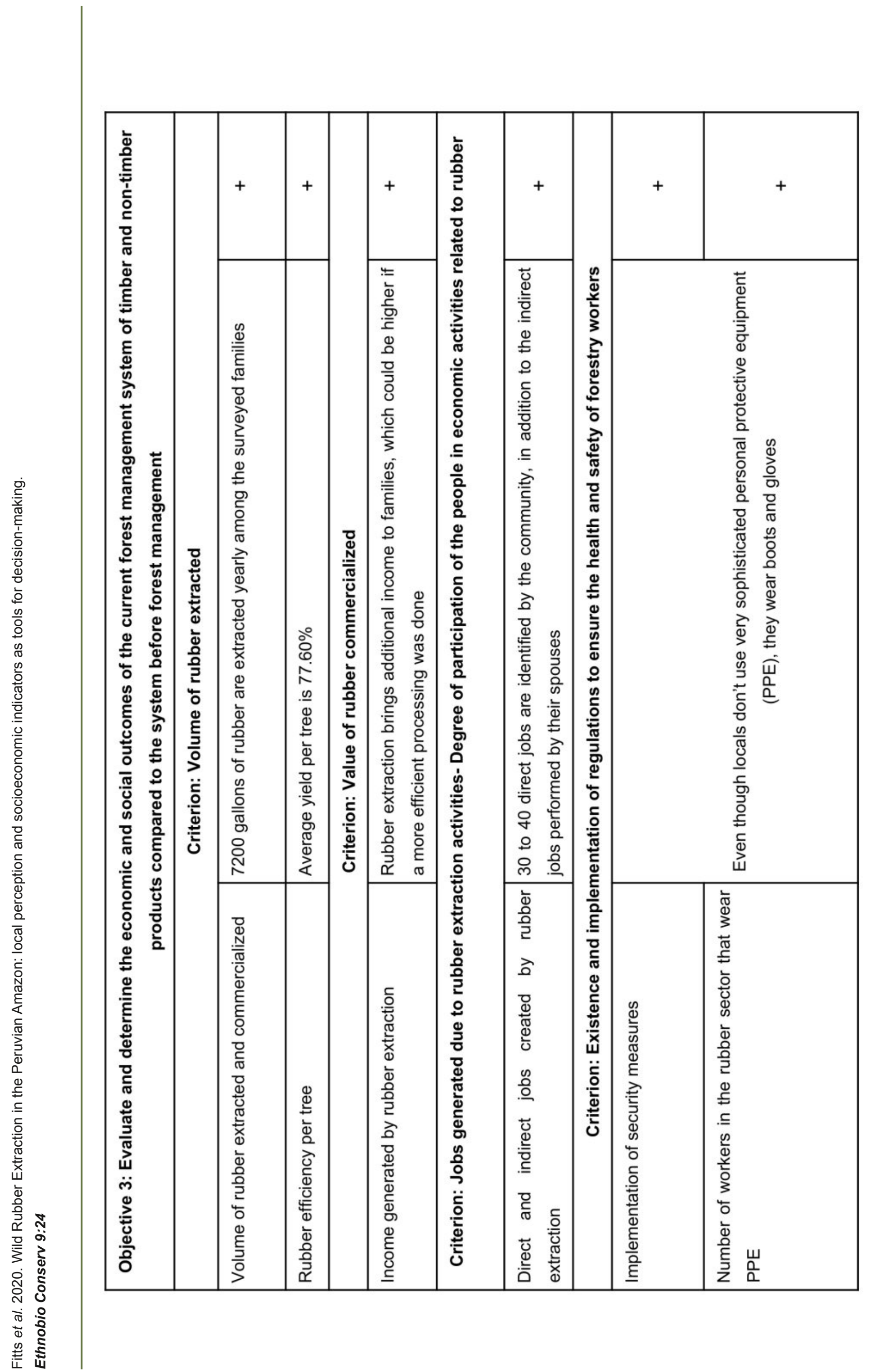




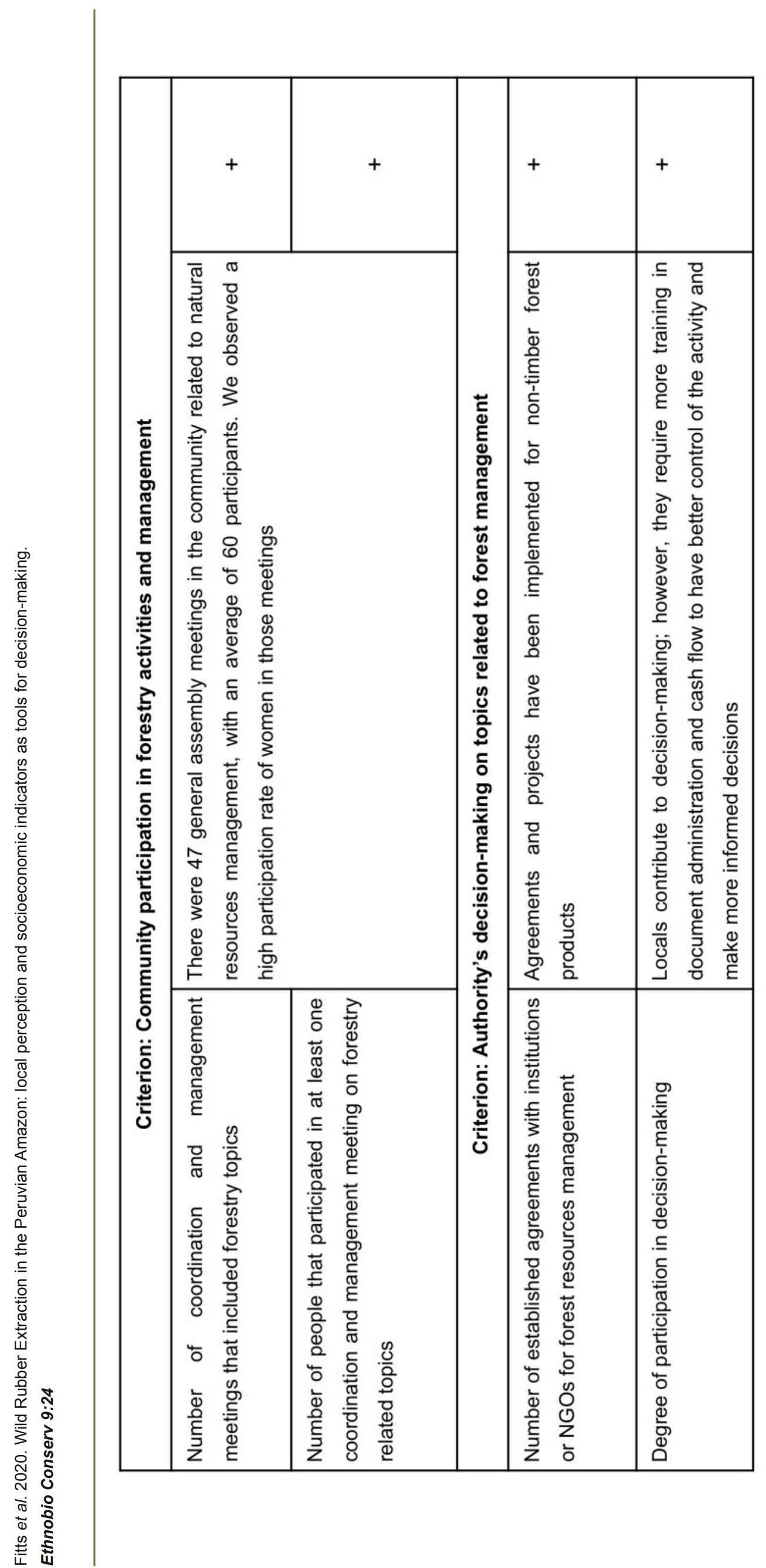


exports their production (SERFOR 2019). The work carried out in these areas report similar yield and willingness to work with rubber to those from Sinchi Roca I that are reported in this paper. This suggests that in Sinchi Roca I, the use and sale of rubber to an external market, with advice and support from external institutions, would improve not only local livelihoods, but also the conservation of the community's forests. These forests constantly present invasion threats and conversion to agricultural activities of higher economic yield, so through wild rubber management, locals can have a sustainable way to contribute to the conservation of these forests.

Overall, wild rubber management in Sinchi Roca I has gone through different stages in which community, family, and individual perceptions towards the resource have changed by different events that occurred in their community and neighboring communities that work with rubber. Our results show that the perceived satisfaction and benefits towards the resource were overall positive for men and women but some negative perceptions are present within the community. In terms of benefits of extracting rubber from a natural forest, we observed that the most notable ones were the income and jobs created. Despite these varied perceptions, there is a tradition, persistence, and hope that with the support of cooperatives or the Government, the use, processing, and subsequent sale of products derived from rubber, can be a sustainable economic activity for local livelihoods. The positive perception that Sinchi Roca I members have towards rubber (which is contrary to perception towards management of other forest products) could be attributed to gender participation, unsuccessful previous experiences with other products (such as timber), and the time that external agents (AIDER, DEVIDA, CNF) have been working in the community as discussed below. On the other hand, the marked difference in perception about the condition of the forest would respond, as pointed out by Sunderland et al. (2014) and Cruz-Burga et al. (2019) to men's greater knowledge of the diversity present in the forest. They have a more general vision that they build by carrying out activities associated with extraction for subsistence and sale. Likewise, the minority perception of improvement in the condition of the forest would be consistent with inadequate forest management within the community (lack of monitoring), which led to sanctions by the Government for non-compliance with its management plans.

During the process of wild rubber extraction in Sinchi Roca I, women had a higher participation in forest management than what is usually observed in other communities, which was reinforced by the absence of notable differences found in gender opinion through the criteria and indicators analyzed. On the other hand, despite the higher participation of women in Sinchi Roca I, men's opinion is given more weight and they participate more in decisionmaking, basically due to traditions, language ability and knowledge of the topic. Some female interviewees felt that men got upset when a woman spoke in a meeting; therefore, women pointed out that they prefer to attend but just to listen. We observed that even though women have received training on natural resources and feel prepared to contribute in the meetings, they generally do not participate as expected. Furthermore, women mentioned they feel that they do not speak Spanish as well as men do, so they usually participate less in the meetings where institutions are present and Spanish is spoken instead of 
the Kakataibo language. During our time at Sinchi Roca I, we observed that in general men have a greater command of the Spanish language because of their higher level of education, their involvement in commerce and their constant visits to the towns and cities near the community. They also show greater knowledge of resource management issues and are better informed about the situation of the community, including the agreements the community has with different institutions for extracting resources. Despite these difficulties, it is interesting that engineers who have worked in the community commented that in Sinchi Roca I there is a greater contribution and participation of females than in other Kakataibo communities. This situation is usually seen in forest management studies, where women have a lower rate of participation and decreased decision power (Sunderland et al. 2014). For instance, Khan and Khisa (2000) show that women had a very low participation rate in an agroforestry project with rubber, and studies in REDD+ projects suggest that women have less power than men in decision-making (Mwangi 2018). Evans et al. (2017) show that even though both men and women believed that women participated in decision-making, participation was of low efficacy.

Sinchi Roca I has had several unsuccessful previous experiences with timber products due to the different agreements they made with external institutions, who unfairly distributed benefits (only $20-30 \%$ of the income would go to the community), as reported by the community members. The most recent company that worked with them was Forestal Nieto S.A.C. whose operations were perceived negatively and failed to promote economic growth in Sinchi Roca I. Therefore, locals have a low expectation of future outcomes when new projects or companies come to work with timber. In addition, there is currently not as much support from NGOs and other institutions as previously. A big problem observed in this study was that locals got used to having constant assistance and support from external institutions in diverse projects, so they do not know how to carry on a project without that support. Consequently, locals are involved in working on a project only while the institution responsible for the project is present in the area. After the project's timeframe expires, native communities tend to abandon the project and the previous efforts are lost. Therefore, NGOs are opting for compound projects with rubber and cacao or other products to offer a variety of economic activities that are more profitable altogether. The success that the CNF had on the two rubber projects (2-3 years-long each) might be due to the fact that they worked on an activity that had been carried out by community members for a long time and the CNF reinforced it. Rubber extraction was already an activity of interest in the community. However, it should be noted that projects that outside institutions carry out tend to be of a short duration. Therefore, only short-term impacts can be measured and not the mid or long-term impacts, which can show a different outcome (Brunner et al. 2005). The establishment and consolidation phase for a project to effectively show results needs to be longer (Donovan et al. 2008).

Our results coincide with prior studies for community forestry in different contexts, which have reported both positive and negative outcomes for CFM initiatives with rubber; however, most of them were done in a plantation or agroforestry context. For example, for positive outcomes, Khan and Khisa (2000) report that despite the 
inequitable distribution of land to farmers in Bangladesh, rubber used in an agroforestry system brought social and economic benefits by creating a basis of livelihood, such as employment, improvement of public services in the area, and access to land for the locals. In addition, Lahjie et al. (2018) mention positive incomes in a rubber plantation system, with maximum production at 17 years. Nevertheless, Jaramillo-Giraldo et al. (2017) find that rubber extraction in natural forests is not economically viable without government subsidies, mainly because of the high costs and low density of trees per hectare, which are not profitable if the product is undifferentiated raw rubber. We might observe the same results in Sinchi Roca I if external support from third parties was not present. Overall, results from previous CFM projects are not directly comparable due to a lack of standards, common design, context and duration, among other indicators (Bowler et al. 2012; Pagdee et al. 2006; Rasolofoson et al. 2015), but are useful to design forest management priorities considering the lessons learnt from other projects. Findings of this study relate specifically to this study case, and results should not be extrapolated directly to other communities.

\section{CONCLUSIONS}

This study has shown that rubber extraction has a positive socioeconomic perception among the people that live in Sinchi Roca I. The main goal of the current study was to evaluate and analyze local perceptions and determine the socioeconomic impact of the current system of forest management for rubber. One major finding was that women in the community participate in the wild extraction activity, as well as in the decision-making in community assemblies, which is not common in other native communities of the region. However, Sinchi Roca I women prefer not to participate actively in meetings with external institutions.

The second major finding was that the most frequent perceived benefit from rubber extraction is the income the population receives for their basic household needs. The annual income for those families interviewed amounted to US\$ 557.80 (1812.90 PEN), from the 30 to 40 direct jobs created by the rubber extraction for the community that were identified by locals. Overall, rubber extraction, through the participation of a development project, has a positive socioeconomic perception of impact, with a considerably higher potential for use and management by the community.

Overall, considering that the CNF has been working with the community on different projects, an improvement on human capital has been observed, both for silvicultural techniques and commercialization of the product. However, there are still several topics to be enhanced, such as more training on quality control, diversification of products, and governance. Despite the benefits found, rubber extraction still needs to be improved to take better advantage of existing potential. Locals possess little information on the benefits that proper silviculture techniques have in the yield and quality of the product. Furthermore, there is still the need to empower and accompany the community in natural resources management in their territory through training and their effective participation to make community forestry projects sustainable over time. Results from this study will be a tool for decision-making as they will help NGOs, local and national government institutions, and other policymakers prioritize forest management 
activities and projects in native communities that go along with communities' interests. In addition, it will promote enforcing actions to enhance sustainable economic activities for locals. By knowing the current situation on rubber extraction, decision-makers can identify areas of improvement and where to put more effort based on the result of previous conservation efforts. To complement this study, we recommend further research to determine the ecological impacts of rubber extraction in this community, which were not analyzed here, following similar methodologies to the ones described in this paper.

\section{ACKNOWLEDGEMENTS}

We would like to express our gratitude to the people of the Sinchi Roca I native community; to the AIDER NGO and the Universidad Nacional Agraria La Molina for funding this research; to the National Forestry Chamber of Peru for the support and information provided; to the research team that was part of field data collection: Ray Medina, Renato Ruiz and Paola Monzón; as well as to the Center for Writing (SWS) at the University of Minnesota and SERFOR and WWF-Peru for updated information on rubber management in Peru.

\section{DATA AVAILABILITY}

The data used in this research are available from the corresponding author upon request.

\section{CONFLICTS OF INTEREST}

The authors have no conflicts of interest to declare.

\section{CONTRIBUTION STATEMENT}

Conceived of the presented idea: LAF, ZACB.

Carried out the experiment: LAF.

Carried out the data analysis: LAF, MALTC.

Wrote the first draft of the manuscript: LAF, ZACB.

Review and final write of the manuscript: LAF, ZACB, MALTC.

Supervision: ZACB, MALTC.

\section{REFERENCES}

Aguilar-Barojas S (2005) Fórmulas para el cálculo de la muestra en investigaciones de salud. Salud en Tabasco 11(1-2): 333-338.

AIDESEP (2013) Relacionamiento entre las comunidades y las empresas forestales: Guía 3. Asociación Interétnica de Desarrollo de la Selva Peruana, Ucayali, Perú.

Álvarez J, Rojas M, Araujo A (2004) Una experiencia de manejo comunal de los recursos del bosque en la Reserva Nacional Alpahuayo Mishana. Iquitos, Perú.

Álvarez J, Shany N (2012) Una Experiencia de Gestión Participativa de La Biodiversidad Con Comunidades Amazónicas. Revista Peruana de Biología 19 (2):223-32.

Barclay F (2012) Los indígenas del Putumayo, tras 100 años no han sido reparados, ni de palabra ni de obra. In: La fiebre del caucho y los crudeness del Putumayo. Boletín temático (67). Lima: Servindi. [http://servindi.org/pdf/Bol67_Putumayo.pdf] Accessed 18 January 2020

Bernard HR (2006) Research methods in cultural anthropology 4ed. USA: SAGE Publication.

Bowler DE, Buyung-Ali LM, Healey JR, Jones JPG, Knight TM, Pullin AS (2012) Does Community Forest Management Provide Global Environmental Benefits and Improve Local Welfare? Frontiers in Ecology and the Environment doi.org/10.1890/110040. 
Bray DB, Duran E, Ramos VH, Mas JF, Velazquez A, McNab RB, Barry D, Radachowsky J (2008) Tropical Deforestation, Community Forests, and Protected Areas in the Maya Forest. Ecology and Society doi.org/10.5751/ES-02593-130256.

Brunner R, Steelman T, Coe-Juell L, Cromley C, Edwards C, Tucker D (2005) Adaptive Governance: Integrating Science, Policy, and Decision Making. New York: Columbia University Press, USA.

Bueno, C, Piber E, Sologuren C (2006) El Proceso del manejo forestal responsable en la Comunidad Nativa de Callería Análisis de la contribución económica y social. [http://www.aider.com.pe/publicaciones/Manejo\% 20forestal\%20en\%20Caller\%C3\%ADa\%20AIDE R.pdf.] Accessed 15 April 2017.

Chi VK, Van Rompaey A, Govers G, Vanacker V, Schmook B, Hieu N. (2013) Land transitions in Northwest Vietnam: an integrated analysis of biophysical and socio-cultural factors. Human ecology, 41(1), 37-50. doi.org/10.1007/s10745013-9569-9

CIFOR (1999) The CIFOR Criteria and Indicators Generic Template. Criteria and Indicators Toolbox Series 2 doi.org/10.17528/cifor/000763.

Chirif A (2011) El auge del caucho o el juego de las apariencias. In: CAAAP, IWGIA (eds) Libro Azul Británico Informes de Roger Casemet y otras cartas sobre las atrocidades en el Putumayo. Lima, Peru, pp. 8-25. [https://www.iwgia.org/images/publications/0568_ informe_azul_para_el_eb.pdf] Accessed 25 may 2020.

Coomes O, Takasaki Y, Abizaid C, Arroyo-Mora J (2016) Environmental and Market Determinants of Economic Orientation among Rain Forest Communities: Evidence from a Large-Scale Survey in Western Amazonia. Ecological Economics doi.org/10.1016/j.ecolecon.2016.06.001.

Cruz-Burga Z, Monterroso I, Larson AM, Valencia F, Saldaña J (2019) The impact of formalizing rights to land and forest Indigenous community perspectives in Madre de Dios and Loreto. CIFOR Infobrief 242 DOI: 10.17528/cifor/007156
De-Camino R (2000) Algunas consideraciones sobre el manejo forestal comunitario y su situación en América Latina. [http://www.ccmss.org.mx/wp-

content/uploads/2014/10/Taller_Manejo_Forestal _Comunitario_y_Certificacion_en_America_Latin a.pdf.] Accessed 20 July 2017.

Dev O, Yadav N, Springate-baginski O, Soussan $J$ (2003) Impacts of Community Forestry on Livelihoods in the Middle Hills of Nepal. Journal of Forest and Livelihood 3(1):64-77.

Donovan J, Stoian D, Poole N (2008) Global Review of Rural Community Enterprises. $1^{\circ}$ ed. CATIE, Turrialba, Costa Rica.

Evans K, Flores S, Larson A, Marchena R, Müller $P$, Pikitle A (2017) Challenges for Women's Participation in Communal Forests: Experience from Nicaragua's in Digenous Territories. Women's Studies International Forum $65: 37-46$ doi.org/10.1016/j.wsif.2016.08.004.

FAO (n.d.) Criterios e indicadores para la ordenación forestal sostenible. [http://www.fao.org/forestry/ci/es/] Accessed May 18, 2016.

(2010) Casos ejemplares de manejo forestal sostenible en América Latina y El Caribe.

[http://www.fao.org/fileadmin/user_upload/trainin g_material/docs/casejes.pdf.] Accessed May 18, 2016

FAO and UNEP (2020) The State of the World's Forests 2020. Forests, biodiversity and people. Rome doi.org/10.4060/ca8642en.

García J (2001) En el corazón de las tinieblas del Putumayo, 1890-1932. Fronteras, caucho, mano de obra indígena y misiones Católicas en la nacionalización de la Amazonía. Revista de Indias LXI (223):591-617.

Garnett ST, Burgess ND, Fa JE, FernándezLlamazares Á, Molnár Z, Robinson CJ, Watson JE, Zander KK, Austin B, Brondizio ES, Collier NF, Duncan T, Ellis E, Geyle H, Jackson MV, Jonas $H$, Malmer P, McGowan B, Sivongxay A, Leiper I (2018) A spatial overview of the global importance of indigenous lands for conservation. Nature Sustainability 1(7): 369-374. 
Gaviria A, Sabogal C (2013) Sistematización de seis experiencias de manejo forestal comunitario en la Amazonía peruana. 1 ed. Proyecto Inventario Nacional Forestal y Manejo Forestal Sostenible del Perú ante el Cambio Climático FAO-Finlandia/MINAG-MINAM, Lima, Perú.

GIZ (2012) Aprovechamiento del caucho silvestre por las comunidades nativas en la selva amazónica del Perú. Proyecto Biodiversidad y Cambio Climático en la Reserva Comunal "El Sira" Ficha técnica 3 [http://infobosques.com/portal/wp-

content/uploads/2016/08/FiTe01-EISira-cauchoGFR-2011-12-26.pdf] Accessed 25 May 2020.

Godoy R, Overman H, Apaza L, Byron E, Huanca T, Leonard W, Pérez E, Reyes-García V, Vadez V, Wilkie D, Cubas A, McSweeney K, Brokaw N (2002) Local Financial Benefits of Rainforests: Comparative Evidence from Amerindian Societies in Bolivia and Honduras. Ecological Economics 40(3):397-409

Gomes CV, Vadjunec J.M, Perz S (2012) Rubber tapper identities: Political-economic dynamics, livelihood shifts, and environmental implications in a changing Amazon. Geoforum 43: 260-271.

Gonçalves de Oliveira D, Vidotte MC (2016) The "Pioneer" front in the Amazonia: Struggle and rubber tappers resistance and the invention of the Extrativist Reserves. Revista de Direito Agrário e Agroambiental 2(2):19-35

Held C, Pawlowsk G, Paredes A, Calo I (2015) Cadenas de Valor en el sector forestal del Perú Informe diagnóstico y desarrollo estratégico. Global Green Growth Institute. Freiburg.

Holdridge LR (1987) Ecología basada en zonas de vida. Instituto Iberoamericano de Cooperación para la Agricultura IICA. 3 ed, San José, Costa Rica.

IIAP (2004) Informe final del proyecto Conservación de la biodiversidad y manejo comunal de los recursos naturales en la cuenca del río Nanay. Banco Mundial/GEF, lquitos, Perú.

IIAP (2009) Evaluación económica del aprovechamiento del jebe silvestre (Hevea brasiliensis) en Madre de Dios. Iquitos, Perú [http://iiap.org.pe/Archivos/Publicaciones/PUBL8 16.pdf] Accessed 25 May 2020.
ILO (2019) Implementing the Indigenous and Tribal Peoples Convention Indigenous and Tribal Peoples Convention No. 169: Towards an inclusive, sustainable and just future. [https://www.ilo.org/wcmsp5/groups/public/--dgreports/---dcomm/---

publ/documents/publication/wcms_735607.pdf]

Accessed 25 May 2020.

ITTO (2005a) Status of Tropical Forest Management 2005. International Tropical Timber Organization Status of Tropical Forest Management

[https://www.itto.int/es/sfm/2005/details/id=1801] Accessed 20 July 2017.

ITTO (2005b) Revised ITTO Criteria and Indicators for the Sustainable Management of Tropical Forests Including Reporting Format. ITTO Policy Development Series 15:15:42.

Jaramillo-Giraldo C, Soares B, Carvalho SM, Gonçalves R (2017) Is It Possible to Make Rubber Extraction Ecologically and Economically Viable in the Amazon? The Southern Acre and Chico Mendes Reserve Case Study. Ecological Economics 134:186-97 doi.org/10.1016/j.ecolecon.2016.12.035.

Kajembe GC, Nduwamungu J, Luoga EJ (2006) The Impact of Community-Based Forest Management and Joint Forest Management on the Forest Resource Base and Local People's Livelihoods: Case Studies from Tanzania. Commons southern Africa occasional paper series 8:1-22.

Khan NA, Khisa SK (2000) Sustainable Land Management with Rubber-Based Agroforestry: A Bangladeshi Example of Uplands Community Development. Sustainable Development 8:1-10.

Khasa PD, Dancik BP (1996) Managing for Biodiversity in Tropical Forests. Journal of Tropical Forest 4(1-2):1-31.

Lahjie AM, Isminarti, Simarangkir BDAS, Kristiningrum R, Ruslim Y (2018) Community Forest Management: Comparison of Simulated Production and Financial Returns from Agarwood, Tengkawang and Rubber Trees in West Kutai, Indonesia. Biodiversitas 19(1):126-133.

Mahanty S, Guernier J. Yasmi Y (2009) A fair share? Sharing the benefits and costs of collaborative forest management. The International Forestry Review 11(2):268-280. 
Mansuri G, Rao V (2004) Community-Based and Driven Development: A Critical Review. World Bank Research Observer 19(1):1-39 doi.org/10.1093/wbro//kh012.

Medina G, Pokorny B, Campbell B (2008) Favouring Local Development in the Amazon: Lessons from Community Forest Management Initiatives. Forest Livelihood Briefs CIFOR [http://www.cifor.org/publications/pdf_files/livebrie f/livebrief0802E.pdf] Accessed 20 July 2017.

MINSA-Perú (2015) Informe operacional mensual de malaria en la Comunidad Nativa Sinchi Roca. Pucallpa, Perú.

Mwangi E (2018) REDD+ Benefits: Men Want Cash, Women Want Development. CIFOR Forests

[https://forestsnews.cifor.org/54754/reddbenefits-men-want-cash-women-wantdevelopment?fnl=en.] Accessed 10 April 2019.

Nalvarte J (2015) Manejo forestal comunitario para mitigar el cambio climático: la experiencia de la Comunidad Nativa Callería, Ucayali - Perú. Asociación para la Investigación y Desarrollo Integral - AIDER, Lima, Perú.

Nguyen T, Tran T, Hoang TH (2008) Traditional versus New Forms of Community Forest Management in Vietnam: Can They Contribute to Poverty Alleviation in Upland Forest Areas? [http://iasc2008.glos.ac.uk/conference\%20paper s/papers/N/Nguyen_218801.pdf] Accessed 25 May 2020.

Pagdee A, Kim Y, Daugherty PJ (2006) What Makes Community Forest Management Successful: A Meta-Study from Community Forests throughout the World. Society \& Natural Resources 19(1):33-52.

Peres JBR, Pastore F (2019) Amazon Rubber, A Potential Yet to be Rediscovered. Journal of Polymers and the Environment 27:652-658 doi.org/10.1007/s10924-019-01381-7

Posadas P, González-Jiménez A, Valentín JL (2016) Natural Rubber: Properties and Uses. In: Hamilton JL (ed) Natural Rubber : Properties, Behavior and Applications. Nova Science Publishers, New York, pp. 1-23.

Quinteros B (2001) Distribución natural y determinación edafoclimática de la Uncaria tomentosa (Willd.) y Uncaria guianensis (Aubl) Gmel (Uña de gato) en la cuenca del río Aguaytía. Undergraduate thesis. Universidad Nacional de Ucayali. Pucallpa, Ucayali, Peru.
Rasolofoson RA, Ferraro PJ, Jenkins CN, Jones JPG (2015) Effectiveness of Community Forest Management at Reducing Deforestation in Madagascar. Biological Conservation 184:271-77.

Rebugio LL, Carandang AP, Dizon JT, Pulhin JM, Camacho LD, DonKoo L, Peralta EO (2010) Promoting Sustainable Forest Management through Community Forestry in the Philippines. IUFRO World Series 25:355-368.

Ríos-Cortez A, Torres-Pérez J, Gómez-Guerrero A, Navarro-Martínez A (2012) Relación entre el manejo forestal $y$ el bienestar socioeconómico en dos ejidos de Quintana Roo. Revista Chapingo Serie Ciencias Forestales y del Ambiente 18(2):251-259 doi.org/10.5154/r.rchscfa.2010.08.052.

Sabogal C, de Jong W, Pokorny B, Louman B (2008) Manejo Forestal Comunitario en América Latina: experiencias, lecciones aprendidas y retos para el futuro. Center for International Forestry Research (CIFOR) doi.org/10.17528/cifor/002640.

Salisbury DS, Schmink M (2007) Cows versus rubber: Changing livelihoods among Amazonian extractivists. Geoforum 38(6):1233-1249.

Schaafsma M, Morse-Jones S, Posen P, Swetnam R, Balmford A, Bateman I, Burgess N, Chamshama SAO, Fisher B, Freeman T, Geofrey V, Green RE, Helplwa AS, Hernandez-Sirve A, Hess S, Kajembe GC, Kayharara G, Kilonzo M, Turner RK (2014) The Importance of Local Forest Benefits: Economic Valuation of NonTimber Forest Products in the Eastern Arc Mountains in Tanzania. Global Environmental Change 24 (1):295-305 doi.org/10.1016/j.gloenvcha.2013.08.018.

SERFOR (2020) Sistema Nacional de Información Forestal y de Fauna Silvestre SNIFFS - Componente Estadístico. [http://sniffs.serfor.gob.pe/estadistica/es/tableros/ publicaciones/anuarios] Accessed 2 June 2020.

SERFOR (2019) Comunidades awajún y wampis de Amazonas producen láminas de shiringa para la industria del calzado. Noticias Negocios sostenibles.

[https://www.serfor.gob.pe/noticias/negociossostenibles/comunidades-awajun-y-wampis-deamazonas-producen-laminas-de-shiringa-parala-industria-del-calzado] Accessed 25 May 2020. 
SERFOR (2015) Ley Forestal y Fauna Silvestre $\mathrm{N}^{\circ} 29763$ y sus reglamentos. Bosques Productivos para la vida. Lima, Perú [https://www.serfor.gob.pe/wpcontent/uploads/2016/03/LFFS-Y-SUSREGLAMENTOS.pdf] Accessed 26 May 2020.

Sheil D, Puri P, Basuki I, Van Heist M, Wan M, Liswanti N, Rukmiyati, Sardojo M, Samsoedin I, Sidiyasa K, Chrisandini, Permana E, Mangopo E, Gatzweiler F, Johnson B, Wijaya A (2004) Explorando la biodiversidad, el medio ambiente y las perspectivas de los pobladores en áreas boscosas. Centro para la Investigación Forestal Internacional. Indonesia.

Shyamsundar P, Ghate R (2011) Is Community Forest Management Good for the Environment and the Poor? - A Review. SANDEE Policy Brief 54-11 doi.org/10.1177/0022146514547328.

Sunderland $T$, Achdiawan $R$, Angelsen $A$, Babigumira R, Ickowitz A, Paumgarten F, ReyesGarcía V, Shively G (2014) Challenging Perceptions about Men, Women, and Forest Product Use: A Global Comparative Study. World Development 64(1):S56-S66

Trovatti E, Sabino MG, Carvalho AJF (2016) Natural Rubber Technologies: Reinforcement with cellulose nanofibers and ThermoReversible Cross Link. In: Hamilton JL (ed) Natural Rubber : Properties, Behavior and Applications. Nova Science Publishers, New York, pp. 25-32.

Uribe T (2013) Caucho, explotación y guerra: configuración de las fronteras nacionales y expoliación indígena en Amazonia. Memoria y Sociedad 17(34): 34-48.
Velarde NG, Vásques T, Del Castillo D, Mattos LL (2010) El cultivo de la shiringa en Madre de Dios, Perú: Manual. Instituto de Investigación de la Amazonía Peruana IIAP [http://repositorio.iiap.gob.pe/bitstream/IIAP/402/ 1/velarde_libro_2010.pdf] Accessed 25 May 2020.

Vera $F$ (2014) Los desafíos en gobernanza y manejo forestal comunitario de Los awajún y wampis: lecciones aprendidas. Soluciones Prácticas.

[http://www.solucionespracticas.org.pe/Descarga r/392844/1195269] Accessed 10 April 2019.

World Bank (2016) Indigenous Peoples. Inspection Panel Emerging Lessons 2. Washington, D.C [http://documents.worldbank.org/curated/en/4473 61478156710826/Inspection-Panel-Indigenouspeoples] Accessed 25 May 2020.

WWF-UK (2014) Going Wild for Rubber. Sourcing wild rubber from the Amazon: why you should and how you can. [http://assets.wwf.org.uk/downloads/wwf_a4_rep ort_wild_rubber_web_2_.pdf] Accessed 25 May 2020.

WWF (2015a) Guía técnica para el aprovechamiento y comercialización de látex de shiringa de bosques naturales Empresa Comunal Jebe Natural del MAP Tahuamanu, ECOMUSA.

[https://d144yw6o2d13bk.cloudfront.net/downloa ds/manual_shiringa_final.pdf] Accessed 25 May 2020.

WWF (2015b) Shiringa: Revalorando el bosque amazónico. [https://www.wwf.org.pe/?238570/shiringarevalor andoelbosqueamazonico] Accessed 25 May 2020 .

Received: 13 April 2020

Accepted: 08 June 2020

Published: 16 June 2020 